\title{
PENINGKATAN BERPIKIR KREATIF MAHASISWA MELALUI MODEL PROJECT BASED LEARNING PADA MATA KULIAH MEDIA MANIPULATIF
}

\author{
Djoko Adi Susilo, Rosita Dwi Ferdiani, \\ Tatik Retno Murniasih
}

\begin{abstract}
Abstrak
Tujuan dari penelitian ini adalah mendeskripsikan penerapan model Project Based Learning yang dapat meningkatkan berpikir kreatif mahasiswa Universitas Kanjuruhan Malang pada mata kuliah Media Manipulatif. Dalam Project Based Learning, mahasiswa diberikan tugastugas belajar yang mencakup perencanaan, pelaksanaan, dan pelaporan yang dilakukan dalam kurun waktu tertentu. Penelitian untuk meningkatkan berpikir kreatif mahasiswa melalui Project Based Learning menggunakan pendekatan kualitatif. Jenis penelitian yang digunakan yaitu Penelitian Tindakan Kelas (PTK) untuk memperbaiki dan meningkatkan kualitas pembelajaran yang dilakukan secara bersiklus. Penelitian ini mengacu pada model siklus Kemmis dan Mc Taggart, dimana setiap siklus terdiri atas 4 tahapan yaitu: a) perencanaan, b) tindakan, c) pengamatan, dan 4) refleksi. Hasil penelitian menunjukkan ada peningkatan berpikir kreatif mahasiswa. Berdasarkan hasil tes siklus I, sebanyak 22 mahasiswa dari 35 mahasiswa mencapai kategori minimal cukup kreatif atau $63 \%$ mahasiswa mencapai kategori minimal cukup kreatif. Pada siklus II terjadi peningkatan sebesar 23\% sehingga banyaknya mahasiswa yang mencapai kategori minimal cukup kreatif menjadi $86 \%$.
\end{abstract}

Kata Kunci: kreatif, project based learning, manipulatif

\section{Pendahuluan}

Kreatif menjadi salah satu hal yang sangat penting karena kesuksesan dalam menghadapi masalah berawal dari berpikir kreatif. Berpikir kreatif merupakan awal mula terbentuknya suatu kreativitas. Untuk membuat mahasiswa berpikir kreatif tidaklah mudah, diperlukan upaya dan kerja keras yang serius dari para dosen. Kemampuan berpikir kreatif perlu dilatih sejak dini melalui pembiasaan secara konsisten. Hal ini ditegaskan oleh Ruseffendi 
Peningkatan Berpikir Kreatif Mahasiswa Melalui Model Project Based Learning pada Mata Kuliah Media Manipulatif

(Choridah 2013: 198) bahwa sifat kreatif akan tumbuh pada diri anak bila ia dilatih, dibiasakan sejak kecil untuk melakukan eksplorasi, inkuiri, penemuan, dan pemecahan masalah. Menurut Siswono (dalam Supardi, 2012: 249), “meningkatkan kemampuan berpikir kreatif artinya menaikkan skor kemampuan siswa dalam memahami masalah, kefasihan, fleksibilitas dan kebaruan penyelesaian masalah". Peningkatan kemampuan berpikir kreatif dapat dilakukan melalui pembelajaran di kelas. Selama proses pembelajaran di kelas, guru atau dosen dapat memanfaatkan materi yang dipelajari untuk mengembangkan atau meningkatkan berpikir kreatif mahasiswa.

Salah satu mata kuliah di jurusan pendidikan matematika Universitas Kanjuruhan Malang, yang membutuhkan pemikiran kreatif adalah media manipulatif. Mata kuliah dengan bobot 3 SKS ini membekali mahasiswa agar dapat membuat dan menggunakan media pembelajaran matematika yang disesuaikan dengan materi pelajaran di SMP dan SMA. Pembelajaran media manipulatif ini bertujuan agar mahasiswa dapat mengkaji dan memahami tentang jenis, manfaat dan karakteristik media pembelajaran matematika serta dapat merencanakan, mengelola, merancang dan mengaplikasikan media pembelajaran matematika berupa benda konkrit (manipulatif). Pembuatan media pembelajaran berupa benda konkrit (manipulatif) tidak harus terbuat dari bahan yang mahal. Penggunaan dari bahan habis pakai dan ramah lingkungan yang diprioritaskan. Hal ini dimaksudkan untuk membentuk karakter mahasiswa untuk lebih peduli terhadap lingkungan. Adapun bahan habis pakai yang dapat digunakan adalah kalender, koran, bekas botol minuman, dan lain-lain.

Sebelum membuat media pembelajaran berupa media manipulatif yang disesuaikan dengan materi di SMP dan SMA, mahasiswa diharuskan untuk memahami konsep tentang materi SMP dan SMA. Karena tanpa pemahaman konsep, mahasiswa akan kesulitan dalam merencanakan, mengelola, membuat dan menggunakan media pembelajaran matematika berupa media manipulatif. 
Berdasarkan hasil angket yang disebarkan pada bulan Februari 2016, kepada mahasiswa prodi Pendidikan Matematika Universitas Kanjuruhan Malang, yang menempuh mata kuliah media manipulatif, penggunaan pembelajaran metode ceramah dan diskusi ternyata kurang efektif. Karena hanya 45 \% mahasiswa yang kreatif dalam merancang media manipulatif. Berdasarkan hasil pretes yang dilaksanakan pada tanggal 3 Maret 2016, kepada 25 mahasiswa angkatan 2013 prodi Pendidikan Matematika Universitas Kanjuruhan Malang, menunjukkan kurangnya berpikir kreatif dalam meyelesaikan soal yang diberikan. Soal pretes yang diberikan berupa soal pemecahan masalah untuk materi SMP. Pemberian pretes ini bertujuan untuk mengetahui pemahaman konsep mahasiswa tentang materi SMP. Dari peserta yang mengikuti pretes, hanya 9 mahasiswa yang menjawab dengan benar atau dengan kata lain hanya 36 \% mahasiswa yang menjawab benar.

Kemampuan berpikir kreatif dapat dikembangkan apabila tercipta keativitas pembelajaran dimana memungkinkan mahasiswa untuk menggunakan imajinasi mereka, mengembangkan ide, menghasilkan beberapa solusi yang mungkin untuk berbagai masalah, serta mengkomunikasikan dalam berbagai media (Margaret dalam Costantino, Tracie, 2011: 3). Salah satu cara mengembangkan atau meningkatkan berpikir kreatif mahasiswa adalah dengan menerapkan model ataupun strategi pembelajaran yang mendorong mahasiswa untuk berpikir kreatif. Salah satu model pembelajaran tersebut adalah Project Based Learning. Menurut Tek (dalam Santi, 2011:76), Project Based Learning menekankan mahasiswa untuk bekerja secara mandiri dalam pembelajarannya dan mengakumulasikan dalam bentuk produk nyata. Dengan pembelajaran berbasis proyek (Project Based Learning), mahasiswa dapat terbiasa memecahkan persoalan nyata. Selain itu mahasiswa akan belajar melakukan penyelidikan dan inkuiri. Peran dosen adalah menyajikan masalah, mendesain pertanyaan, memfasilitasi penyelidikan dan melakukan pembimbingan pada saat pelaksanaan tugas proyek. Dengan pemberian tugas proyek, diharapkan dapat meningkatkan kreatifitas mahasiswa. 
Peningkatan Berpikir Kreatif Mahasiswa Melalui Model Project Based Learning pada Mata Kuliah Media Manipulatif

Penelitian menggunakan model Project Based Learning ini juga telah diujicobakan dan diteliti oleh peneliti-peneliti sebelumnya yaitu Prabowo (2012) dengan melakukan penelitian yang berjudul "Pembelajaran Berbasis Proyek Untuk Meningkatkan Pemahaman Mahasiswa atas Permasalahan Statistika pada Perkuliahan Studi Kasus dan Seminar". Penelitian dengan 2 siklus ini berhasil meningkatkan pemahaman mahasiswa atas permasalahan statistika. Menurut Widiyatmoko, dkk (2012) melalui pembelajaran berbasis proyek dapat mengembangkan dan menghasilkan alat peraga IPA dengan memanfaatkan bahan bekas pada mata kuliah Produksi Media dan Alat Peraga IPA mahasiswa Program Studi Pendidikan IPA semester gasal tahun akademik 2011/2012. Berdasarkan uraian latar belakang yang telah dijabarkan di atas, maka peneliti mengambil judul "Peningkatan berpikir kreatif mahasiswa melalui model Project Based Learning pada mata kuliah Media Manipulatif". Tujuan dari penelitian ini adalah mendeskripsikan penerapan model Project Based Learning yang dapat meningkatkan berpikir kreatif mahasiswa Universitas Kanjuruhan Malang pada mata kuliah Media Manipulatif.

\section{Metode Penelitian}

Penelitian untuk meningkatkan berpikir kreatif mahasiswa melalui Project Based Learning menggunakan pendekatan kualitatif. Penelitian ini mempunyai karakteristik, yaitu 1) berlatar alamiah yang artinya berawal dari masalah nyata yaitu kreatifitas mahasiswa dalam mata kuliah media manipulatif masih kurang, 2) manusia sebagai instrumen, dimana peneliti sebagai instumen utama dalam merencanakan, melaksanakan, mengobservasi, mengumpulkan data, menganalisis data, dan menarik kesimpulan, serta membuat laporan, 3) metode yang digunakan adalah kualitatif, hal ini dikarenakan dalam penelitian dilakukan pengamatan, wawancara dan pendokumentasian, 4) analisis data dalam penelitian ini adalah secara induktif artinya sesuai dengan fakta dan didasarkan data-data yang dikumpulkan sehingga dapat menarik kesimpulan, 5) deskriptif artinya 
penelitian ini bertujuan untuk mendeskripsikan cara untuk meningkatkan berpikir kreatif mahasiswa melalui Project Based Learning pada mata kuliah Media Manipulatif, dan 6) peneliti lebih mementingkan proses daripada hasil. Hal ini tercermin dalam pengamatan proses pembelajaran yang meliputi pengamatan aktivitas peneliti dan mahasiswa pada saat pembelajaran berlangsung.

Jenis penelitian ini adalah penelitian tindakan kelas (PTK), dimana peneliti berkolaboratif dengan dosen serumpun untuk memperbaiki dan meningkatkan kualitas pembelajaran yang dilakukan secara bersiklus. Penelitian ini mengacu pada model siklus yang dikemukan oleh Kemmis dan Mc Taggart. Dalam Penelitian Tindakan Kelas terdapat empat tahap dalam setiap siklusnya yaitu (1) Perencanaan (Planning), (2) Tindakan (acting), (3) Pengamatan (observing), dan 4) refleksi (refleksing), Akbar (2010: 28).

Penelitian untuk meningkatkan berpikir kreatif mahasiswa melalui model Projek Based Learning ini berlokasi di Program Studi Pendidikan Matematika, Universitas Kanjuruhan Malang, yang beralamatkan di Jalan S. Supriyadi, No 48, Kota Malang, Jawa Timur. Penelitian ini akan dilaksanakan pada semester genap tahun ajaran 2016/2017.

Data yang dikumpulkan pada penelitian ini adalah: a) Hasil validasi perangkat pembelajaran dalam lembar validasi, b) Hasil observasi pada mahasiswa saat proses pembelajaran berbasis proyek (Project-based Learning) yaitu produk berupa media pembelajaran manipulatif untuk materi SMP dan SMA, laporan, dan pelaksanan diskusi, c) Tes yang digunakan berupa tes tertulis untuk mengevaluasi seberapa besar kemampuan berpikir kreatif mahasiswa dalam merancang media manipulatif matematika, d) Hasil wawancara terhadap 4 subjek penelitian, dan e) Hasil catatan lapangan selama pembelajaran berlangsung.

Sumber data dalam penelitian ini adalah mahasiswa prodi matematika Universitas Kanjuruhan Malang, observer yang merupakan dosen serumpun, dan validator. Adapun validator mempunyai kriteria sebagai berikut dosen 
Peningkatan Berpikir Kreatif Mahasiswa Melalui Model Project Based Learning pada Mata Kuliah Media Manipulatif

matematika yang telah berpangkat lektor atau lektor kepala dan dosen matematika yang berpendidikan minimal doktor.

Data yang dikumpulkan dalam penelitian ini diperoleh dengan cara:

a) Pengamatan

Pengamatan ini dilakukan dengan cara mengamati setiap aktivitas yang dilakukan dosen dan mahasiswa pada saat pembelajaran berbasis proyek (Projek Based Learning) berlangsung. Pengamat mencatat segala aktivitas dosen dan mahasiswa pada lembar pengamatan yang telah disiapkan. Yang berperan sebagai pengamat adalah 2 orang dosen serumpun dari prodi pendidikan matematika Universitas Kanjuruhan Malang.

b) Tes Tertulis

Pemberian tes bertujuan untuk mengevaluasi seberapa besar kemampuan berpikir kreatif mahasiswa dalam merancang media manipulatif matematika. Tes ini dilakukan dengan 2 cara yaitu tes tulis dan tes lisan. Tes tertulis dilakukan pada setiap akhir siklus. Sedangkan tes lisan dilakukan pada saat bimbingan pelaksaan tugas proyek.

c) Dokumentasi

Untuk memperkuat data yang diperoleh dalam pengamatan, dilakukan pendokumentasian. Dokumentasi ini dapat berupa foto-foto yang menggambarkan pelaksanaan pembelajaran berbasis proyek.

d) Lembar validasi

Lembar validasi pada penelitian ini terdiri dari: (a) lembar validasi Rencana Pelaksanaan Pembelajaran (RPP), (b) lembar validasi instrumen tes, (c) lembar validasi pedoman wawancara, (e) lembar validasi pengamatan aktivitas dosen, dan (f) lembar validasi pengamatan aktivitas mahasiswa.

e) Wawancara

Wawancara dilakukan untuk mengetahui kesulitan atau kendala mahasiswa dalam pelaksanaan pembelajaran berbasis proyek. Wawancara dilakukan setelah pelaksanaan tes tulis. Wawancara dilakukan menggunakan alat perekam. Wawancara dilakukan kepada 4 subyek penelitian. Ketentuan kualifikasi wawancara adalah sebagai berikut: (a) 
Kualifikasi 1 untuk satu mahasiswa dengan perolehan skor nilai berada pada quartil teratas, (b) Kualifikasi 2 untuk dua orang mahasiswa dengan perolehan skor nilai berada pada quartil tengah. (c) Kualifikasi 3 untuk satu orang mahasiswa dengan perolehan skor nilai berada pada quartil terbawah.

f) Catatan Lapangan

Kegunaan catatan lapangan ini adalah untuk memperkuat data yang diperoleh pada saat penelitian. Catatan lapangan merupakan lembar pengamatan pembelajaran yang memuat uraian secara deskriptif tentang pelaksanaan pembelajaran berbasis proyek.

Adapun rancangan penelitian dapat dilihat pada gambar 1. di bawah ini:

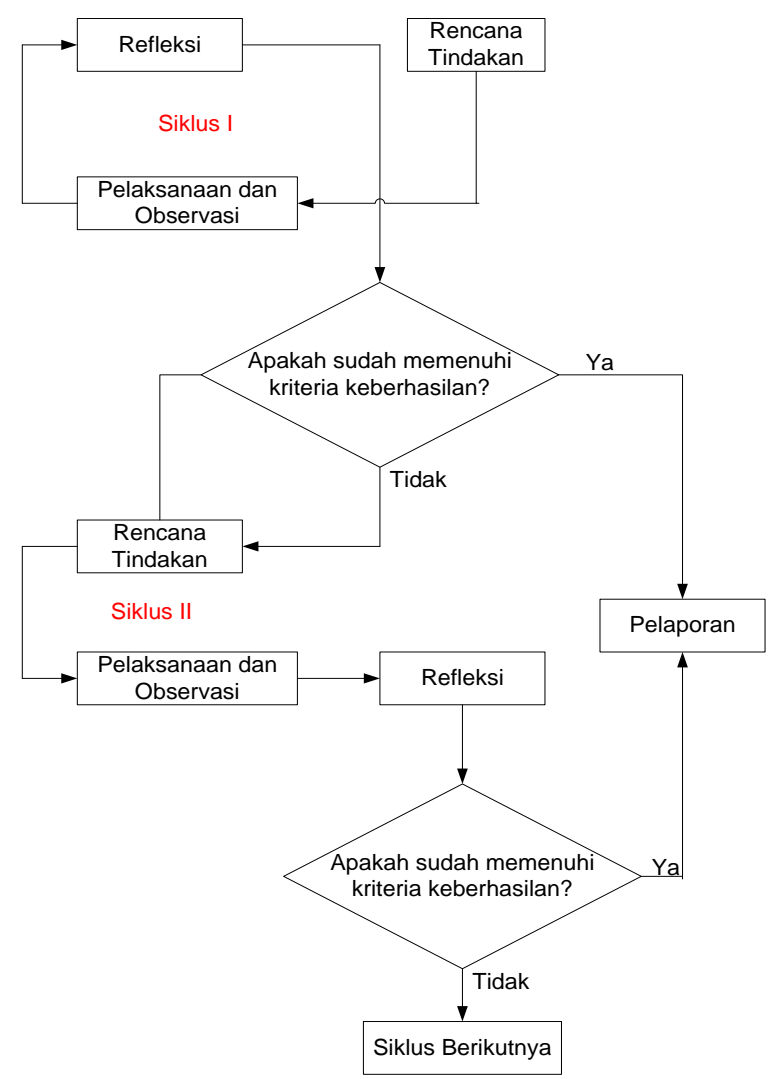

Gambar 1. Rancangan Penelitian (adaptasi dari Murniasih, 2016)

Analisis data dilakukan setelah pengumpulan data. Data yang dianalisis pada penelitian ini adalah data tentang hasil tes belajar mahasiswa 
Peningkatan Berpikir Kreatif Mahasiswa Melalui Model Project Based Learning pada Mata Kuliah Media Manipulatif

serta aktivitas peneliti dan mahasiswa pada saat proses pembelajaran berbasis proyek.

a. Analisis Hasil Tes Belajar Mahasiswa

Penelitian ini difokuskan meningkatkan berpikir kreatif mahasiswa melalui model Project Based Learning. Untuk mengetahui peningkatan berpikir kreatif mahasiswa, peneliti menganalisis tes hasil belajar melalui pemeriksaan keseluruhan hasil tes serta kajian terhadap butir-butir soal tes. Penyusunan butir-butir tes disesuaikan dengan indikator peningkatan berpikir kreatif mahasiswa yaitu pemahaman masalah, kefasihan, fleksibilitas dan kebaruan penyelesaian masalah. Mahasiswa dikatakan memahami masalah bila menunjukkan apa yang diketahui dan apa yang ditanyakan, mahasiswa memiliki kefasihan dalam menyelesaikan masalah bila dapat menyelesaikan masalah dengan jawaban bermacam-macam yang benar secara logika. Mahasiswa memiliki fleksibilitas dalam meyelesaikan masalah bila dapat menyelesaikan soal dengan dua cara atau lebih yang berbeda dan benar. Mahasiswa memiliki kebaruan dalam menyelesaikan masalah bila dapat membuat jawaban yang berbeda dari jawaban sebelumnya atau yang umum diketahui mahasiswa. Tabel peningkatan berfikir kreatif, dapat dilihat pada tabel 1.

\section{Tabel 1. Kriteria Peningkatan Berpikir Kreatif}

\begin{tabular}{|l|c|l|}
\hline \multicolumn{1}{|c|}{ Indikator } & \multicolumn{1}{|c|}{ Skor } & \multicolumn{1}{c|}{ Kategori } \\
\hline Pemahaman mahasalah & $90 \% \leq S \leq 100 \%$ & Sangat kreatif \\
\cline { 2 - 3 } Kefasihan & $70 \% \leq S<90 \%$ & Cukup kreatif \\
\cline { 2 - 3 } Fleksibilitas & $50 \% \leq S<70 \%$ & Kurang kreatif \\
\cline { 2 - 3 } Kebaruan & $0 \% \leq S<50 \%$ & Tidakkreatif \\
\hline
\end{tabular}

Sumber: adaptasi Siswono (dalam Supardi, 2012)

Selain memperhatikan indikator peningkatan berpikir kreatif, peneliti juga memperhatikan ketuntasan belajar mahasiswa. Dalam penelitian ini, mahasiswa dikatakan dapat berpikir kreatif apabila telah memenuhi ke empat kriteria yaitu pemahaman masalah, kefasihan, fleksibilitas dan kebaruan penyelesaian masalah, dengan tingkat pencapaian $\geq 70 \%$ sebanyak $75 \%$ dari total mahasiswa. 
b. Analisis pengamatan aktifitas peneliti dan mahasiwa

Analisis hasil pengamatan aktivitas peneliti maupun mahasiswa digunakan persentase skor rata-rata hasil observasi sebagai berikut:

$$
P s=\frac{S T}{S M} \times 100 \%
$$

$P s=$ persentasi skor rata-rata hasil observasi

ST = skor total hasil observasi dari masing-masing pengamat

SM = skor maksimal yang dapat diperoleh dari hasilobservasi

Kriteria standar aktivitas mahasiswa atau peneliti dapat dilihat pada tabel 2.

\section{Tabel 2. Kriteria Standar aktivitas mahasiswa dan peneliti}

\begin{tabular}{|c|l|}
\hline Kriteria Standar & \multicolumn{1}{|c|}{ Kategori } \\
\hline $90 \% \leq$ PS $\leq 100 \%$ & Sangat Baik \\
\hline $70 \% \leq$ PS $<90 \%$ & Cukup Baik \\
\hline $50 \% \leq$ PS $<70 \%$ & Kurang Baik \\
\hline $0 \% \leq$ PS $<50 \%$ & Tidak Baik \\
\hline
\end{tabular}

Keberhasilan dari penelitian ini yaitu apabila persentase skor rata-rata aktivitas mahasiswa dan peneliti minimal berada pada kategori cukup baik.

Pengecekan keabsahan data dilakukan untuk menghindari kesalahan atau kekeliruan data yang telah terkumpul. Kriteria derajat kepercayaan (crebility) dalam pengecekan keabsahan data didasarkan pada teknik triangulasi, ketekunan pengamatan, pengecekan teman sejawat. Penelitian ini menggunakan teknik triangulasi dengan sumber, yang artinya membandingkan derajat kepercayaan suatu informasi yang diperoleh melalui sumber yang berbeda. Ketekunan pengamatan dilakukan dengan diteliti, rinci dan terus menerus selama proses pembelajaran berlangsung yang diikuti dengan kegiatan wawancara secara intensif terhadap mahasiswa. Pengecekan teman sejawat/kolega dilakukan dalam bentuk diskusi mengenai proses dan hasil penelitian dengan harapan untuk memperoleh masukan baik dari segi metodelogi maupun pelaksanaan tindakan. 
Peningkatan Berpikir Kreatif Mahasiswa Melalui Model Project Based Learning pada Mata Kuliah Media Manipulatif

\section{Hasil dan Pembahasan}

Sebelum penelitian, dilakukan validasi perangkat pembelajaran dan instrumen penelitian. Validasi dilakukan oleh 2 orang ahli yaitu ahli pembelajaran matematika dan ahli materi. Berdasarkan hasil validasi, terdapat hal-hal yang perlu diperbaiki yaitu: jumlah soal disesuaikan dengan waktu pengerjaan. Berdasarkan hasil validator pertama didapat saran untuk memperbaiki soal pretes. Jumlah soal pretes sebaiknya disesuaikan dengan waktu yang disediakan. Jumlah soal yang semula 5 diubah menjadi 4 soal dengan waktu 40 menit. Setelah melakukan perbaikan dari validator pertama, peneliti menyerahkan hasil revisian kepada validator kedua. Validator kedua memberikan saran untuk memperbaiki penulisan agar dapat dimengerti oleh mahasiswa. Setelah perangkat pembelajaran dan instrumen penelitian dari 2 orang validator selesai peneliti revisi, peneliti langsung menggunakan perangkat dan instrumen penelitian untuk melaksanakan penelitian.

Peneliti melakukan pretest untuk mengetahui pengetahuan prasyarat mahasiswa tentang materi SMP dan SMA. Pretest diikuti oleh 35 mahasiswa kelas 2013A yang mengikuti matakuliah Media Manipulatif. Berdasarkan hasil prestest didapatkan hasil rata-rata sebesar 65 . Hal ini menunjukkan mahasiswa sudah cukup memahami materi matematika SMP dan SMA dan memenuhi syarat untuk mempelajari materi media manipulatif. Pelaksanaan prestest berjalan dengan tertib dan lancar. Tetapi terdapat beberapa mahasiswa yang masih melakukan kesalahan dalam mengerjakan soal pretest. Kesalahan mengerjakan prestest disebabkan kurangnya pemahaman terhadap soal yang diberikan, salah satunya adalah soal tentang persamaan linier dua variabel pada materi SMP

Kelas VIII. Kesalahan yang dilakukan dikarenakan mahasiswa belum bisa:

1) Membuat model matematika dari permasalahan yang diberikan.

2) Menentukan nilai variabel dari persamaan matematika yang telah dibuat. 
3) Mengartikan maksud dari nilai variabel yang diperoleh, dan menghubungkannya dengan permasalahan sehingga diperoleh jawaban dari permasalahan.

Kesalahan yang dilakukan mahasiswa saat mengerjakan soal tentang persamaan linier dua variabel dapat ditunjukkan pada gambar 3 di bawah ini:

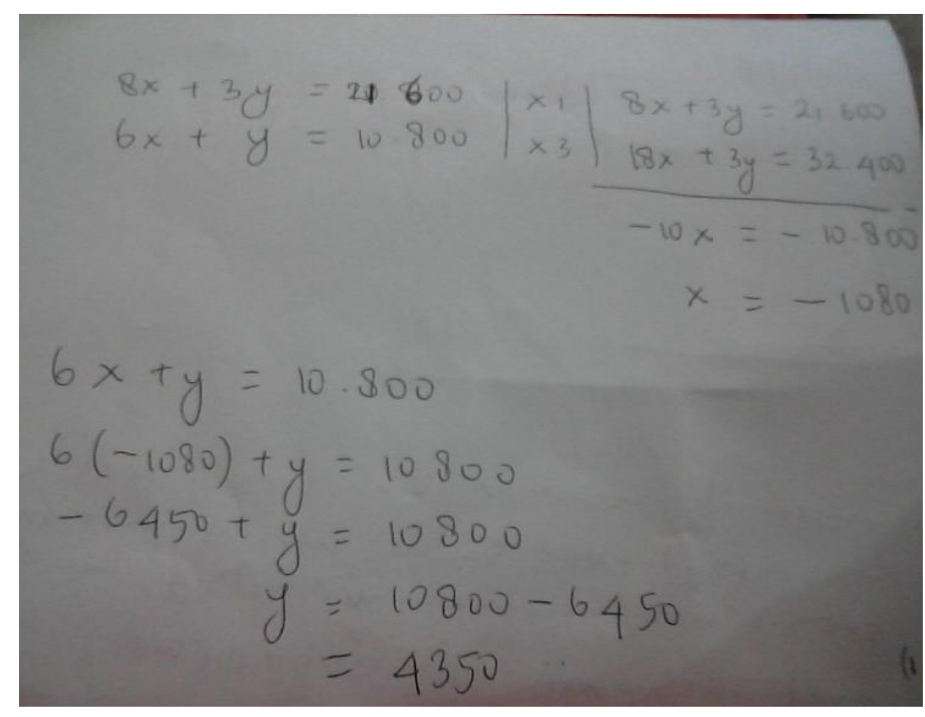

\section{Gambar 3. Contoh Hasil Pekerjaan Mahasiswa P}

Pada gambar 3, mahasiswa $\mathrm{P}$ keliru pada saat mencari nilai variabel $\mathrm{x}$, seharusnya $x$ bernilai positip 1080. Hal ini menyebabkan langkah pengerjaan berikutnya menjadi keliru, sehingga didapatkan jawaban akhir yang salah.

Tindakan I, dilakukan selama 2 kali pertemuan tatap muka dan 1 kali pertemuan tes akhir. Rencana kegiatan tindakan I dapat dilihat pada tabel 3 , di bawah ini:

\section{Tabel 3. Rencana Kegiatan Tindakan I}

\begin{tabular}{|c|l|}
\hline Pertemuan ke- & \multicolumn{1}{c|}{ Kegiatan } \\
\hline I & $\begin{array}{l}\text { a. Penentuan Pertanyaan Mendasar (Start With The } \\
\text { Essential Question) oleh peneliti. } \\
\text { b. Mendesain Perencanaan Proyek (Design a Plan for } \\
\text { the Project) oleh peneliti dan mahasiswa. } \\
\text { c. Menyusun Jadwal (Create a Schedule) oleh peneliti. }\end{array}$ \\
\hline II & $\begin{array}{l}\text { Menguji Hasil (Assess the Outcome) berupa presentasi } \\
\text { hasil karya 3 kelompok. }\end{array}$ \\
\hline III & Tes Akhir \\
\hline
\end{tabular}


Peningkatan Berpikir Kreatif Mahasiswa Melalui Model Project Based Learning pada Mata Kuliah Media Manipulatif

Berdasarkan hasil tes yang dilaksanakan pada tindakan 1 yang berjumlah 22 dari 35 mahasiswa mencapai kategori cukup kreatif atau dengan kata lain, sebanyak 63\% mahasiswa mencapai kategori cukup kreatif. Pengamatan dilakukan bersamaan dengan peneliti melakukan tindakan. Pengamatan dilakukan oleh 2 orang observer, secara rata-rata aktivitas pembelajaran pada tindakan I berada pada kategori minimal baik.

Refleksi dilakukan untuk menentukan apakah tindakan I telah berhasil atau belum. Hasil refleksi pada tindakan I adalah:

a) Mahasiswa masih merasa kesulitan dalam menjawab pertanyaan mendasar. Hal ini dikarenakan sebagian mahasiswa kurang memahami materi di SMP atau SMA.

b) Pada saat mendesain perencanaan proyek yang akan dibuat, mahasiswa merasa kesulitan untuk memunculkan ide tentang apa media pembelajaran yang cocok untuk menjelaskan konsep materi SMP atau SMA yang dipilih.

c) Pada saat pengujian hasil karya berupa presentasi, mahasiswa masih kesulitan menyampaikan pendapat.

d) Berdasarkan hasil tes akhir tindakan 1 diperoleh hasil yang belum mencapai kriteria keberhasilan yang ditentukan.

e) Berdasarkan hasil pengamatan oleh kedua observer didapatkan hasil dalam kriteria minimal baik.

Berdasarkan hasil refleksi tindakan I, kriteria keberhasilan belum terpenuhi sehingga harus dilanjutkan pada tindakan II.

Pelaksanaan kegiatan pembelajaran pada tindakan II terdiri dari 3 kegiatan yaitu kegiatan awal, kegiatan inti, dan kegiatan akhir. Penjabaran dari kegiatan tindakan II dapat dilihat pada tabel 4 berikut ini. 
Tabel 4. Kegiatan Pembelajaran Tindakan II

\begin{tabular}{|c|c|}
\hline Pertemuan ke- & Kegiatan \\
\hline 1 & $\begin{array}{l}\text { Pada pertemuan 1, kegiatan pembelajaran dibagi } \\
\text { menjadi } 3 \text { bagian yaitu: } \\
\text { a. Kegiatan Awal } \\
\text { - Apersepsi } \\
\text { - Menyampaikan tujuan pembelajaran yaitu } \\
\text { merancang media pembelajaran manipulatif untuk } \\
\text { materi SMP yaitu Sistem Pertidaksamaan Linier dan } \\
\text { Aljabar } \\
\text { - Memberikan Motivasi akan penting media } \\
\text { pembelajaran manipulatif dalam kehidupan } \\
\text { sehari - hari. } \\
\text { b. Kegiatan Inti } \\
\text { - Penyajian hasil karya berupa presentasi } \\
\text { rancangan media pembelajaran manipulatif. } \\
\text { c. Penutup } \\
\text { Membuat kesimpulan dan merumuskan hasil } \\
\text { kerja kelompok. }\end{array}$ \\
\hline II & $\begin{array}{l}\text { Pada pertemuan 2, Kegiatan pembelajaran dibagi } \\
\text { menjadi } 3 \text { bagian yaitu: } \\
\text { a. Kegiatan Awal } \\
\text { - Apersepsi } \\
\text { - Menyampaikan tujuan pembelajaran yaitu } \\
\text { merancang media pembelajaran manipulatif } \\
\text { untuk materi SMP yaitu Himpunan dan Lingkaran. } \\
\text { - Memberikan Motivasi akan penting media } \\
\text { pembelajaran manipulatif dalam kehidupan } \\
\text { sehari - hari. } \\
\text { b. Kegiatan Inti } \\
\text { - Menguji Hasil (Assess the Outcome) berupa } \\
\text { presentasi hasil karya } 2 \text { kelompok. } \\
\text { c. Penutup } \\
\text { Membuat kesimpulan berdasarkan presentasi kerja } \\
\text { kelompok. }\end{array}$ \\
\hline III & Tes Akhir \\
\hline
\end{tabular}

Berdasarkan hasil tes yang dilaksanakan pada tindakan II yang berjumlah 30 dari 35 mahasiswa mencapai kategori cukup kreatif atau dengan kata lain, sebanyak 86 \% mahasiswa mencapai kategori cukup kreatif. Hasil pengamatan pembelajaran yang dilakukan 2 orang observer pada Tindakan 2, didapatkan rata-rata aktivitas pembelajaran minimal pada 
Peningkatan Berpikir Kreatif Mahasiswa Melalui Model Project Based Learning pada Mata Kuliah Media Manipulatif

kategori sangat baik. Tindakan II sudah memenuhi kriteria keberhasil yang ditetapkan peneliti sehingga tindakan II dihentikan.

\section{Kesimpulan}

Pembelajaran menggunakan model Project Based Learning dapat meningkatkan berpikir kreatif mahasiswa pada matakuliah media manipulatif. Hal ini dapat dilihat dari hasil tes pada tindakan I sebanyak 63\% mahasiswa mencapai kategori cukup kreatif dan pada tindakan II meningkat menjadi 86\% mahasiswa mencapai kategori cukup kreatif. Pembelajaran menggunakan model Project Based Learning dibagi menjadi 3 kegiatan yaitu: a) Awal meliputi: apersepsi, tujuan dan motivasi, b) Inti berisi penyajian hasil karya berupa presentasi rancangan media pembelajaran manipulatif, serta c) Penutup berisi kesimpulan dari presentasi hasil kerja kelompok.

\section{Daftar Pustaka}

Akbar, Sa'dun. (2010). Penelitian Tindakan Kelas (Edisi Revisi). Yogyakarta: Cipta Media.

Choridah, Dedeh Tresnawati. (2013). Peran Pembelajaran Berbasis Masalah Untuk Meningkatkan Kemampuan Komunikasi Dan Berpikir Kreatif Serta Disposisi Matematis Siswa SMA. Jurnal Ilmiah Program Studi Matematika STKIP Siliwangi Bandung, Vol 2, No.2

Costantino, Tracie. (2011). "International Journal of Education \& the Arts". IJEA. Vol. 12. No. 7 hal: 1-6

Murniasih, TR. 2016. Penggunaan Media Manipulatif Untuk Meningkatkan Pemahaman Konsep Siswa Pada Teorema Pythagoras. Prosiding Seminar Pendidikan Matematika dengan tema "Pengembangan 4C's dalam Pembelajaran Matematika: Sebuah Tantangan dalam Pengembangan Kurikulum Matematika" pada tanggal 28 Mei 2016 yang diselenggarakan oleh Prodi S2-S3 Pendidikan Matematika Pascasarjana Universitas Negeri Malang. online: https://goo.gl/0QuHYz diakses tanggal 20 Juli 2017.

Prabowo, Ardhi. (2012). Pembelajaran Berbasis Proyek Untuk Meningkatkan Pemahaman Mahasiswa atas Permasalahan Statistika pada Perkuliahan Studi Kasus dan Seminar. Jurnal Kreano, ISSN 
:2086-2334. Diterbitkan oleh Jurusan Matematika FMIPA UNNES. Volume 3 Nomor 2.

Santi, Triana Kartika. (2011). Pembelajaran Berbasis Proyek (Project Based Learning) Untuk Meningkatkan Pemahaman Mata Kuliah Fisiologi Tumbuhan. Jurnal IImiah PROGRESSIF, Vol. 7 No. 21.

Supardi U.S. (2012). Peran Berpikir Kreatif Dalam Proses Pembelajaran Matematika. Jurnal Formatif 2(3): 248-262. Hal 249

Widiyatmoko, S.D. Pamelasari. (2012). Pembelajaran Berbasis Proyek Untuk Mengembangkan Alat Peraga IPA Dengan Memanfaatkan Bahan Bekas Pakai Pendidikan IPA Indonesia. Dapat diakses di http://journal.unnes.ac.id/index.php/jpii

\section{Djoko Adi Susilo}

Universitas Kanjuruhan

E-mail: heni.adisusilo@gmail.com

\section{Rosita Dwi Ferdiani}

Universitas Kanjuruhan

E-mail: Rositazahra22@gmail.com

Tatik Retno Murniasih

Universitas Kanjuruhan

E-mail: tretnom@unikama.ac.id 